\title{
The role of drugs in the treatment of autism
}

\section{SUMMARY}

The prevalence of autism spectrum disorder is increasing. It usually presents in childhood with abnormal behaviour and development.

The diagnosis can be difficult. There are often comorbidities which can cause confusion.

Non-drug treatments are first line. Drug treatment is not effective for the core symptoms of autism spectrum disorder. However, drugs may have a role in managing comorbidities and related symptoms, such as irritability and aggression.

Anxiety is a common comorbidity. Cognitive behaviour therapy can be effective, but in some cases selective serotonin reuptake inhibitors may have a role.

Most patients have problems sleeping, but drugs are not usually used to treat sleep disorders in children.

Antipsychotics, such as risperidone, may be considered for irritability and aggression. Clonidine is first line for children with Tourette syndrome. Patients need regular monitoring because of the adverse effects of these drugs.

\section{Introduction}

The number of people with autism spectrum disorder is growing throughout the western world, partly due to changes in diagnostic methods and criteria.' In 2018 there were 205,200 Australians with autism, a 25.1\% increase from the 164,000 with the condition in $2015 .^{2}$ The symptoms usually begin in early childhood with the child experiencing problems with social skills, speech and behaviour. Comorbidities are common.

The challenges in managing the disorder are wide and varied. They include:

- communicating with those who have poor speech and language skills

- differentiating the clinical features of autism spectrum disorder from the symptoms of emerging or current mental illness

- determining a treatment plan that addresses very challenging symptoms such as aggression, agitation, impulsivity and obsessions

- $\quad$ avoiding polypharmacy where possible, while also treating a range of mental illnesses.

Many of the drugs prescribed in autism spectrum disorder have limited supporting evidence and some have significant adverse effects so monitoring is required. The impact of drug therapy on the patient and their family must be taken into account. ${ }^{3}$

\section{Pathophysiology}

The current hypotheses propose that autism spectrum disorder is caused by, at least in part, dopamine signalling abnormalities in the brain. ${ }^{4}$ This impacts on the prefrontal cortex and the mesocorticolimbic circuit ${ }^{5}$ which affect behaviour and emotional regulation.

There have been many other postulated neurotransmitter-related causes. ${ }^{5}$ These include reduced GABAergic gene expression, increases in glutamate transport proteins, and serotonin transporter gene polymorphisms. Dopamine, glutamate and serotonin have therefore been considered as targets for drug treatment.

\section{Comorbidity}

Studies show a high rate of comorbid mental illness in autism spectrum disorder. In one study $74 \%$ of young people with autism spectrum disorder had at least five comorbidities. ${ }^{6}$ Another study reported comorbidity rates of:

- $28 \%$ for attention deficit hyperactivity disorder (ADHD)

- $20 \%$ for anxiety disorders

- $13 \%$ for sleep-wake disorders

- $12 \%$ for disruptive, impulse-control and conduct disorders

- $11 \%$ for depressive disorders

- $9 \%$ for obsessive compulsive disorder

- $5 \%$ for bipolar disorders

- $4 \%$ for schizophrenia spectrum disorders. ${ }^{7}$

It is important to remember that a deterioration in behaviour may not be directly related to the disorder. For example, it may be triggered by an underlying physical illness.

\section{Melanie Turner}

Child and adolescent psychiatrist, and Director, MyChild Psychiatry and Psychology, Norwood, South Australia

Senior clinical lecturer University of Adelaide

\section{Keywords}

antipsychotic drugs, autism spectrum disorder. selective serotonin reuptake inhibitors

Aust Prescr 2020;43:185-90 https://doi.org/10.18773/ austprescr.2020.054 


\section{Non-drug treatment}

Non-drug therapies are first-line interventions, particularly for children under seven or eight years of age, to try and assist with their developmental trajectory. The strategies that are used include psychology-based therapy with cognitive behaviour therapy, narrative therapy, schema therapy and positive behaviour support. ${ }^{3}$ Occupational therapy can assist with fine and gross motor skills, interoception skills and social skills. ${ }^{8}$

\section{Drug-treatment strategies}

Drugs may be added to augment non-drug therapies or to help with comorbidities. Historically, the most common drugs used for autism spectrum disorder were antipsychotics such as haloperidol. ${ }^{9}$ As diagnostic definitions were clarified, modern drugs, including atypical antipsychotics, were studied in children with psychiatric diagnoses. ${ }^{10}$

There have been many small studies, case reports and open-label trials in children with autism spectrum disorder." It is important to focus on a low starting dose and a slow increase to reach the best, but lowest, dose for each patient. The Centre for Interventional Paediatric Psychopharmacology and Rare Diseases in the UK suggests that drug treatment begins with small doses (usually an eighth to a sixth of the typical dose), increasing after about 5-6 half-lives of the drug. For most drugs used in Australia that is an increase every three to seven days. A longer titration time is needed for fluoxetine because its active metabolite, norfluoxetine, has a half-life of 9-14-days. ${ }^{12}$

A large concern for all doctors looking after patients with autism spectrum disorder is the risk of polypharmacy. In one study polypharmacy was seen in $34 \%$ of the patients who received drug treatment. ${ }^{13}$ However, patients often present with symptoms suggestive of changes in different systems of the brain and it may not be possible to use one drug to treat all the symptoms.

The Table outlines the drugs that may be considered for specific indications. ${ }^{14-17}$ Antipsychotic drugs should only be started by a psychiatrist or paediatrician or in consultation with one. For all antipsychotics ongoing monitoring is required. If possible, monitor weight, fasting lipids, blood glucose, prolactin and liver function every six months with more frequent monitoring at the start of treatment at one month and three months.

\section{Anxiety and depression}

Anxiety is one of the most common comorbidities with autism. There are links to difficulties with social communication and therefore the internal discomfort that can be experienced when in groups, going to new environments and when experiencing change. Talking-based therapies, in particular cognitive behaviour therapy, have good supporting evidence. ${ }^{18}$ These techniques are harder to use in children and adults with a severe autism spectrum disorder who find working in a therapeutic relationship and speaking to a therapist about distressing feelings to be intolerable. Drugs have a role when anxiety is interfering in the functional life of a child, such as avoiding school, losing friendships or ceasing activities that were previously enjoyable.

The first-line drugs are selective serotonin reuptake inhibitors (SSRIs) such as sertraline, fluoxetine and fluvoxamine. ${ }^{19}$ The onset adverse effects of fluvoxamine, ${ }^{20}$ which include agitation and anxiety, limit its use as a first-line drug. It is often used after a failed trial of sertraline or fluoxetine.

To provide the low doses required for some SSRIs, a compounding chemist may be needed to prepare a low-concentration liquid form.

Sertraline, fluoxetine and fluvoxamine can be used for depressive disorders, however there are less research data from children with autism spectrum disorder and a mood disorder. Treatment is considered on a caseby-case basis after specialist assessment. ${ }^{3}$ There is the risk for increased suicidal thinking occurring when using SSRIs. The harm-benefit ratio for each patient needs to be considered as well as monitoring for an increase in suicidal thinking in the first two weeks of treatment."1

\section{Mood lability}

Children with autism spectrum disorder who present with externalising behaviours, which are behaviours that are targeted toward the external environment when distressed such as physical aggression, threats and destroying property, often have a labile mood. They also often have learning disorders, poor self-regulation and behavioural problems at school.

Sodium valproate can be helpful with aggression and is also used to treat irritability and mood lability. ${ }^{21}$ There are insufficient data to indicate the use of other mood stabilisers. Sodium valproate has many adverse effects including nausea, poor attention, skin reactions including Stevens-Johnson syndrome, and liver toxicity. It is best avoided in females because of its teratogenicity and has also been associated with polycystic ovary syndrome.

\section{Tics and Tourette syndrome}

Clonidine is the first-line treatment for tics and Tourette syndrome. There is evidence that atypical antipsychotics such as aripiprazole can also be used for treatment. Aripiprazole reduces the symptoms of Tourette syndrome, and can be used when there 


\begin{tabular}{|c|c|c|c|c|}
\hline Drug & Dose & Half-life & Best indication & Common adverse effects in young people \\
\hline Sertraline & $\begin{array}{l}\text { Start } 0.5 \mathrm{mg} / \mathrm{kg} \text {, up to } 2 \mathrm{mg} / \mathrm{kg} \text {. } \\
\text { Gradual dose increases are recommended. Common dose } \\
\text { range is } 50-200 \mathrm{mg} \text { a day. Alternatively: } \\
\text { - over } 6 \text { years - start at } 25 \mathrm{mg} \text { and increase to } 50 \mathrm{mg} \text { after } \\
1 \text { week then by } 25 \mathrm{mg} \text { monthly } \\
\text { - } 6 \text {-18 years - maximum dose } 200 \mathrm{mg} \text { a day. }\end{array}$ & 27 hours & $\begin{array}{l}\text { Anxiety disorders, particularly } \\
\text { generalised anxiety disorder }\end{array}$ & $\begin{array}{l}\text { In younger children agitation, labile mood. Risk } \\
\text { of increased suicidal thinking } \\
\text { Withdrawal symptoms if the dose is not tapered } \\
\text { off slowly }\end{array}$ \\
\hline Fluoxetine & $\begin{array}{l}\text { Start } 0.5 \mathrm{mg} / \mathrm{kg} \text {, up to } 1 \mathrm{mg} / \mathrm{kg} \text {. } \\
\text { Average dose for } 7-12 \text { years - } 20-30 \mathrm{mg} \text { a day. } \\
12 \text { years and over with eating disorders or obsessive } \\
\text { compulsive disorder - up to } 60 \mathrm{mg} \text { may be needed. } \\
\text { The maximum dose for other diagnoses is } 40 \mathrm{mg} \text { a day. } \\
\text { Alternatively: } \\
\text { - under } 12 \text { years - start at } 5 \mathrm{mg} \text { and increase by } 5 \mathrm{mg} \text { monthly } \\
\text { to a maximum of } 30 \mathrm{mg} \\
\text { - } 12 \text { years and over - the maximum dose is } 40 \mathrm{mg} \text { for major } \\
\text { depression and } 60 \mathrm{mg} \text { for obsessive compulsive disorder. }\end{array}$ & $\begin{array}{l}\text { Active metabolite } \\
\text { norfluoxetine } \\
9-14 \text { days }\end{array}$ & $\begin{array}{l}\text { Depression, obsessive compulsive } \\
\text { disorder, eating disorder symptoms } \\
\text { including avoidant restrictive food } \\
\text { intake disorder }\end{array}$ & $\begin{array}{l}\text { Nausea, headaches, agitation, insomnia } \\
\text { Tablets have a strong aversive flavour } \\
\text { Risk of increased suicidal thinking }\end{array}$ \\
\hline Fluvoxamine & $\begin{array}{l}0.5 \mathrm{mg} / \mathrm{kg} \text { up to } 2 \mathrm{mg} / \mathrm{kg} \text {. } \\
\text { Maximum dose generally } 150 \mathrm{mg} \text { (divided doses once } 100 \mathrm{mg} \\
\text { a day is given). } \\
\text { Alternatively: } \\
\text { - over } 8 \text { years - start at } 25 \mathrm{mg} \text { and increase by } 25 \mathrm{mg} \text { monthly. }\end{array}$ & 15.6 hours & $\begin{array}{l}\text { Obsessive compulsive disorder, } \\
\text { significant anxiety disorders }\end{array}$ & $\begin{array}{l}\text { Agitation, restlessness, onset and offset adverse } \\
\text { effects when starting and weaning } \\
\text { Risk of increased suicidal thinking }\end{array}$ \\
\hline Sodium valproate & $\begin{array}{l}5 \mathrm{mg} / \mathrm{kg} \text { once a day for } 2 \text { weeks then increase if needed for } \\
\mathrm{mood} \text {, up to maximum of } 20 \mathrm{mg} / \mathrm{kg} \text { (divided doses once over } \\
200 \mathrm{mg} \text { a day). }\end{array}$ & $8-20$ hours & $\begin{array}{l}\text { Can help with mood lability and } \\
\text { aggression particularly in those with } \\
\text { comorbid intellectual impairment }\end{array}$ & $\begin{array}{l}\text { Nausea, metallic taste, fatigue, weight gain, } \\
\text { poor attention, Stevens-Johnson syndrome, liver } \\
\text { toxicity } \\
\text { Sevenfold increase in polycystic ovary syndrome } \\
\text { Need to monitor blood concentrations, but many } \\
\text { children with autism spectrum disorder cannot } \\
\text { tolerate venepuncture }\end{array}$ \\
\hline Risperidone & $\begin{array}{l}\text { Over } 5 \text { years and below } 20 \mathrm{~kg}-0.25 \mathrm{mg} \text { once daily for } \\
3 \text { days, then increase to } 0.5 \mathrm{mg} \text { daily. If necessary, increase } \\
\text { by } 0.25 \mathrm{mg} \text { every } 2 \text { weeks. Usual range } 0.5-1.5 \mathrm{mg} \text { daily. } \\
\text { Over } 5 \text { years and over } 20 \mathrm{~kg}-0.5 \mathrm{mg} \text { once daily for } 3 \text { days, } \\
\text { then increase to } 1 \mathrm{mg} \text { daily. If necessary, increase daily } \\
\text { dose by } 0.5 \mathrm{mg} \text { every } 2 \text { weeks. Usual range } 1-2.5 \mathrm{mg} \text { daily, } \\
\text { maximum } 3 \mathrm{mg} \text { daily. }\end{array}$ & $3-20$ hours & $\begin{array}{l}\text { Used in autism spectrum disorder, } \\
\text { approved by Therapeutic Goods } \\
\text { Administration, best for agitation, } \\
\text { aggression, impulsivity }\end{array}$ & $\begin{array}{l}\text { Weight gain, increased appetite including } \\
\text { hoarding of food at times }\end{array}$ \\
\hline
\end{tabular}


Table Drugs that can be considered for comorbidities in children with autism ${ }^{14-17,27}$ (continued)

\begin{tabular}{|c|c|c|c|c|}
\hline Drug & Dose & Half-life & Best indication & Common adverse effects in young people \\
\hline Aripiprazole & $\begin{array}{l}\text { 6-18 years - } 2.5 \mathrm{mg} \text { once daily for } 1 \text { week, then } 5 \mathrm{mg} \text { once } \\
\text { daily. If necessary, increase daily dose in } 5 \mathrm{mg} \text { increments } \\
\text { at intervals of at least a week, to a maximum of } 15 \mathrm{mg} \\
\text { once daily. }\end{array}$ & 75 hours & Agitation, irritability & $\begin{array}{l}\text { Less weight gain than risperidone but little } \\
\text { sedation and can be an activating drug }\end{array}$ \\
\hline \multirow[t]{2}{*}{ Olanzapine } & $\begin{array}{l}\text { 13-18 years if under } 40 \mathrm{~kg}-2.5 \mathrm{mg} \text { at night, maximum dose } \\
5 \mathrm{mg} \text {. }\end{array}$ & $21-54$ hours & \multirow{4}{*}{$\begin{array}{l}\text { Aggression and mood lability when } \\
\text { risperidone, aripiprazole and sodium } \\
\text { valproate have not been effective }\end{array}$} & \multirow{4}{*}{$\begin{array}{l}\text { Significant sedation, weight gain and } \\
\text { hypersalivation }\end{array}$} \\
\hline & $\begin{array}{l}\text { 13-18 years if over } 40 \mathrm{~kg} \text { - up to } 5 \mathrm{mg} \text { at night, maximum } \\
\text { dose } 10 \mathrm{mg} \text {. }\end{array}$ & & & \\
\hline \multirow[t]{2}{*}{ Quetiapine } & $\begin{array}{l}\text { Over } 13 \text { years old and under } 40 \mathrm{~kg}-25 \mathrm{mg} \text { at night, increase } \\
\text { to } 25 \mathrm{mg} \text { twice a day (or } 50 \mathrm{mg} \text { long-acting) if tolerated, } \\
\text { maximum dose } 50 \mathrm{mg} \text { a day. }\end{array}$ & \multirow[t]{2}{*}{ 7-12 hours } & & \\
\hline & $\begin{array}{l}\text { Over } 13 \text { years old and over } 40 \mathrm{~kg}-25 \mathrm{mg} \text { at night and } \\
\text { increase up to maximum dose } 100 \mathrm{mg} \text { a day if tolerated. }\end{array}$ & & & \\
\hline \multirow[t]{2}{*}{ Atomoxetine } & $0.5 \mathrm{mg} / \mathrm{kg}$ a day increasing after at least 3 days. & \multirow[t]{2}{*}{17 hours } & \multirow{2}{*}{$\begin{array}{l}\text { ADHD, slightly better results for } \\
\text { inattention }\end{array}$} & \multirow[t]{2}{*}{ Nausea, fatigue ${ }^{27}$} \\
\hline & Maximum 1.2-1.4 mg/kg a day or $100 \mathrm{mg}$, whichever is lower. & & & \\
\hline \multirow[t]{3}{*}{ Methylphenidate } & Under 12 years - 5 mg twice a day. & Children: 2.5 hours & \multirow[t]{3}{*}{ ADHD } & \multirow{3}{*}{$\begin{array}{l}\text { Weight loss, poor weight gain, palpitations, } \\
\text { agitation }\end{array}$} \\
\hline & Over 12 years - 10 mg twice a day. & \multirow[t]{2}{*}{ Adults: 3.5 hours } & & \\
\hline & Maximum 60 mg daily. & & & \\
\hline \multirow[t]{2}{*}{ Dexamfetamine } & $\begin{array}{l}6-12 \text { years - start at } 2.5 \mathrm{mg} \text { daily and increase at weekly } \\
\text { intervals. Usual maximum is } 20 \mathrm{mg} \text { in } 2 \text { divided doses. }\end{array}$ & \multirow{4}{*}{12 hours } & \multirow{4}{*}{ ADHD } & \multirow{4}{*}{$\begin{array}{l}\text { Weight loss, poor weight gain, palpitations, } \\
\text { agitation }\end{array}$} \\
\hline & $\begin{array}{l}\text { Over } 12 \text { years }-5 \mathrm{mg} \text { every morning, daily dose may be } \\
\text { increased by } 5 \mathrm{mg} \text { at weekly intervals until optimal response. } \\
\text { Maximum } 40 \mathrm{mg} \text { a day. }\end{array}$ & & & \\
\hline \multirow[t]{2}{*}{ Lisdexamfetamine } & $\begin{array}{l}6-18 \text { years }-30 \mathrm{mg} \text { once each morning - if necessary, } \\
\text { increase the daily dose by } 20 \mathrm{mg} \text { at intervals of at least } \\
\text { a week. }\end{array}$ & & & \\
\hline & Maximum 70 mg daily. & & & \\
\hline \multirow[t]{3}{*}{ Guanfacine } & Starting dose of $1 \mathrm{mg}$ & \multirow[t]{3}{*}{$10-30$ hours } & \multirow[t]{3}{*}{ ADHD } & \multirow[t]{3}{*}{ Fatigue, weight gain ${ }^{27}$} \\
\hline & Under 11 years - increase to maximum of $4 \mathrm{mg}$ a day. & & & \\
\hline & Over 11 years - increase to maximum of $7 \mathrm{mg}$ a day. & & & \\
\hline
\end{tabular}

ADHD attention deficit hyperactivity disorder 
is little response to psychological interventions or when there is a contraindication or no response to clonidine. ${ }^{22}$ Aripiprazole may be better tolerated than clonidine. ${ }^{23}$

\section{Irritability and aggression}

Aggression is one of the most common sources of concern for parents of children with autism spectrum disorder. It can cause large interruptions in their schooling, relationships, their ability to leave the home and it can greatly disrupt a family.

Often antipsychotics such as aripiprazole and risperidone have been used to help treat irritability and problem behaviours in children and adolescents with autism spectrum disorder. ${ }^{24,25}$ In Australia, risperidone is approved by the Therapeutic Goods Administration for irritability and aggression in autism in patients under 18 years of age. However, the risks with risperidone include weight gain, elevated lipids, blood glucose and prolactin, and interruption of puberty. Aripiprazole has been used in other countries, in particular the USA, as it causes less weight gain and has less effect on prolactin. It is not as sedating as risperidone and this can cause difficulties for families if they have been using risperidone to settle night-time aggression and to improve sleep.

Before prescribing, record height, weight, menarche and regularity of menstruation, blood glucose, fasting lipids and prolactin. Monitor these again after one month and then six-monthly. An increase in prolactin or the development of abnormal muscle movements requires the drug dose to be lowered and a review of the antipsychotic therapy.

At present, due to small sample sizes and openlabel studies, there is insufficient evidence to show that antipsychotics such as olanzapine, quetiapine, ziprasidone or clozapine are effective in autism spectrum disorder. ${ }^{10,11}$ There is also little evidence that older antipsychotics, antiepileptic drugs and glutaminergic modulators (such as ketamine and memantine) are helpful in managing aggression. ${ }^{25}$ Sodium valproate can be tried if antipsychotics are not effective or the patient cannot tolerate them. ${ }^{21}$

For some patients with a poor response to risperidone and aripiprazole, off-label use of an alternate antipsychotic can be considered. ${ }^{26}$

\section{Attention deficit hyperactivity disorder}

ADHD is a common comorbidity with autism spectrum disorder., ${ }^{7,27}$ The drugs used in treatment are the same as those used for ADHD alone, namely methylphenidate, dexamfetamine, guanfacine and atomoxetine. ${ }^{27}$ Stimulant treatment improves the symptoms of ADHD in patients with autism spectrum disorder. Atomoxetine can assist with inattentive ADHD and patients with comorbid anxiety symptoms. The adverse effects include nausea and fatigue. ${ }^{28}$

\section{Insomnia}

Insomnia and sleep disorders affect close to $80 \%$ of people with autism spectrum disorder, and often present as a sleep onset disorder. Behavioural management is the mainstay of treatment.

There are few drugs that are useful for sleep disorders in children. Benzodiazepines are not recommended. Antipsychotics should also be avoided because of their high risk of adverse effects. Melatonin is often used to manage sleep disorders in children, partly because it is available over-the-counter in overseas countries. It has a low risk of adverse effects and dependency. ${ }^{29}$ Clonidine in low dose (50-200 microgram at night) has also been used, in particular when the insomnia is secondary to stimulant treatment.

\section{Conclusion}

Many patients and families seek medical-based intervention for the core symptoms of autism spectrum disorder including social and emotional skills, rigid thinking and poor theory of mind. For these features of autism spectrum disorder nondrug treatments are first line and are focused on psychology input, social skills groups, peer mentors, and support in education and employment.

Assistance with managing aggression and irritable behaviours may be obtained by using risperidone or aripiprazole, with risperidone having the most research-based data at present. There is little evidence for the use of other antipsychotics or glutaminergic drugs such as ketamine and memantine.

The most common comorbidity is anxiety and SSRIs can be helpful. The possibility of comorbid ADHD is important to consider. Comorbid ADHD can be treated with the same drugs as ADHD alone and for some patients it can be used with an antipsychotic to manage hyperactivity, inattention and aggression.

Polypharmacy should be avoided if possible but comorbid conditions need to be addressed. However, the use of an atypical antipsychotic for aggression and irritability, plus an SSRI for an anxiety disorder or drugs for ADHD, may be needed for patients with these common comorbidities. $<$
SELF-TEST QUESTIONS

True or false?

1. Dexamfetamine is the first-choice drug for managing the core symptoms of autism spectrum disorder.

2. Risperidone should not be used in patients with irritability, related to autism spectrum disorder, under the age of 18 years.

Answers on page 225 


\section{REFERENCES}

1. King M, Bearman P. Diagnostic change and the increased prevalence of autism. Int J Epidemiol 2009;38:1224-34. https://doi.org/10.1093/ije/dyp261

2. Australian Bureau of Statistics. Autism in Australia. In: 4430.0 - Disability, ageing and carers, Australia: summary of findings, 2018. www.abs.gov.au/statistics/ health/disability/disability-ageing-and-carers-australiasummary-findings/latest-release [cited 2020 Nov 1]

3. Howes OD, Rogdaki M, Findon JL, Wichers RH, Charman T, King $\mathrm{BH}$, et al. Autism spectrum disorder: consensus guidelines on assessment, treatment and research from the British Association for Psychopharmacology. J Psychopharmacol 2018;32:3-29. https://doi.org/10.1177/ 0269881117741766

4. Pavăl D. A dopamine hypothesis of autism spectrum disorder. Dev Neurosci 2017;39:355-60. https://doi.org/ $10.1159 / 000478725$

5. Eissa N, Al-Houqani M, Sadeq A, Ojha SK, Sasse A, Sadek B Current enlightenment about etiology and pharmacological treatment of autism spectrum disorder. Front Neurosci 2018;12:304. https://doi.org/10.3389/fnins.2018.00304

6. Joshi G, Petty C, Wozniak J, Henin A, Fried R, Galdo M, et al. The heavy burden of psychiatric comorbidity in youth with autism spectrum disorders: a large comparative study of a psychiatrically referred population. J Autism Dev Disord 2010;40:1361-70. https://doi.org/10.1007/s10803-010-0996-9

7. Lai MC, Kassee C, Besney R, Bonato S, Hull L, Mandy W, et al. Prevalence of co-occurring mental health diagnoses in the autism population: a systematic review and metaanalysis. Lancet Psychiatry 2019;6:819-29. https://doi.org/ $10.1016 /$ S2215-0366(19)30289-5

8. National Institute for Health and Care Excellence (NICE). Autism spectrum disorder in under 19s: support and management. Clinical guideline CG170. 2013 Aug 28. http://www.nice.org.uk/guidance/cg170 [cited 2020 Nov 1]

9. Faretra G, Dooher L, Dowling J. Comparison of haloperidol and fluphenazine in disturbed children. Am J Psychiatry 1970;126:1670-3. https://doi.org/10.1176/ajp.126.11.1670

10. Campbell M, Cueva JE. Psychopharmacology in child and adolescent psychiatry: a review of the past seven years. Part I. J Am Acad Child Adolesc Psychiatry 1995;34:1124-32. https://doi.org/10.1097/00004583-199509000-00008

11. Hollander E, Phillips AT, Yeh CC. Targeted treatments for symptom domains in child and adolescent autism. Lancet 2003;362:732-4. https://doi.org/10.1016/ S0140-6736(03)14236-5

12. Santosh PJ, Singh J. Drug treatment of autism spectrum disorder and its comorbidities in children and adolescents. BJPsych Adv 2016;22:151-61. https://doi.org/10.1192/ apt.bp.115.014597

13. Murray ML, Hsia Y, Glaser K, Simonoff E, Murphy DG, Asherson PJ, et al. Pharmacological treatments prescribed to people with autism spectrum disorder (ASD) in primary health care. Psychopharmacology (Berl) 2014;231:1011-21. https://doi.org/10.1007/s00213-013-3140-7

14. US Food and Drug Administration. Drugs@FDA: FDAapproved drugs. www.accessdata.fda.gov/scripts/cder/daf [cited 2020 Nov 1]

15. Stahl Online. The prescriber's guide. 6th ed. Cambridge: Cambridge University Press; 2020. https://stahlonline.cambridge.org/prescribers_guide.jsf [cited 2020 Nov 1]

16. Shann F. Drug doses. 17th ed. Melbourne: Collective Pty Ltd; 2017.
17. AMH Children's Dosing Companion. Adelaide: Australian Medicines Handbook; 2020. https://childrens.amh.net.au [cited 2020 Nov 1]

18. Wood JJ, Drahota A, Sze K, Har K, Chiu A, Langer DA. Cognitive behavioral therapy for anxiety in children with autism spectrum disorders: a randomized, controlled trial. J Child Psychol Psychiatry 2009;50:224-34. https://doi.org/ 10.1111/j.1469-7610.2008.01948.x

19. Nadeau J, Sulkowski ML, Ung D, Wood JJ, Lewin AB, Murphy TK, et al. Treatment of comorbid anxiety and autism spectrum disorders. Neuropsychiatry (London) 2011;1:567-78. https://doi.org/10.2217/npy.11.62

20. Reinblatt SP, DosReis S, Walkup JT, Riddle MA. Activation adverse events induced by the selective serotonin reuptake inhibitor fluvoxamine in children and adolescents. J Child Adolesc Psychopharmacol 2009;19:119-26. https://doi.org/10.1089/cap.2008.040

21. Hollander E, Chaplin W, Soorya L, Wasserman S, Novotny S, Rusoff J, et al. Divalproex sodium vs placebo for the treatment of irritability in children and adolescents with autism spectrum disorders. Neuropsychopharmacology 2010:35:990-8. https://doi.org/10.1038/npp.2009.202

22. Quezada J, Coffman KA. Current approaches and new developments in the pharmacological management of Tourettes Syndrome. CNS Drugs 2018;32:33-45. https://doi.org/10.1007/s40263-017-0486-0

23. Hollis C, Pennant M, Cuenca J, Glazebrook C, Kendall T, Whittington $C$, et al. Clinical effectiveness and patient perspectives of different treatment strategies for tics in children and adolescents with Tourette syndrome: a systematic review and qualitative analysis. Health Technol Assess 2016;20:1-450. https://doi.org/ 10.3310/hta20040

24. Lake JK, Denton D, Lunsky Y, Shui AM, Veenstra-VanderWeele J, Anagnostou E. Medical conditions and demographic, service and clinical factors associated with atypical antipsychotic medication use among children with an autism spectrum disorder. J Autism Dev Disord 2017;47:1391-402. https://doi.org/10.1007/s10803-017-3058-8

25. Fung LK, Mahajan R, Nozzolillo A, Bernal P, Krasner A, Jo B, et al. Pharmacologic treatment of severe irritability and problem behaviours in autism: a systematic review and meta-analysis. Pediatrics 2016:137 Suppl 2:S124-35 https://doi.org/10.1542/peds.2015-2851K

26. Fitzpatrick SE, Srivorakiat L, Wink LK, Pedapati EV, Erickson CA. Aggression in autism spectrum disorder: presentation and treatment options. Neuropsychiatr Dis Treat 2016;12:1525-38. https://doi.org/10.2147/ndt.s84585

27. Antshel KM, Russo N. Autism spectrum disorders and ADHD: overlapping phenomenology, diagnostic issues, and treatment considerations. Curr Psychiatry Rep 2019;21:34. https://doi.org/10.1007/s11920-019-1020-5

28. Patra S, Nebhinani N, Viswanathan A, Kirubakaran R. Atomoxetine for attention deficit hyperactivity disorder in children and adolescents with autism: a systematic review and meta-analysis. Autism Res 2019;12:542-52. https://doi.org/10.1002/aur.2059

29. Abdelgadir IS, Gordon MA, Akobeng AK. Melatonin for the management of sleep problems in children with neurodevelopmental disorders: a systematic review and meta-analysis. Arch Dis Child 2018;103:1155-62. https://doi.org/10.1136/archdischild-2017-314181 